\title{
The Reception of Victor Segalen in China
}

\section{Between Literature and Ideology}

\section{Bai Yunfei}

Translator. Jonathan Hall

\section{(2) OpenEdition \\ Journals}

Electronic version

URL: http://journals.openedition.org/chinaperspectives/6927

DOI: 10.4000/chinaperspectives.6927

ISSN: 1996-4617

Publisher

Centre d'étude français sur la Chine contemporaine

\section{Printed version}

Date of publication: 1 March 2016

Number of pages: $59-63$

ISSN: 2070-3449

\section{Electronic reference}

Bai Yunfei, «The Reception of Victor Segalen in China », China Perspectives [Online], 2016/1 | 2016,

Online since 01 March 2016, connection on 24 September 2020. URL : http://journals.openedition.org/ chinaperspectives/6927; DOI : https://doi.org/10.4000/chinaperspectives.6927 


\section{The Reception of Victor Segalen}

in China

Between Literature and Ideology

BAI YUNFEI

ABSTRACT: The French doctor, archaeologist, novelist, and poet Victor Segalen (1878-1919) was known above all for his works inspired by China and his theory of the "Diverse." Despite the numerous studies devoted to him in recent years, very few Western researchers have taken any interest in the reception of his work in China. By focusing critically on the latest research by Chinese specialists on the author of Stèles, this review essay will attempt to show that Segalen owes his undeniable success in China not only to the intrinsic worth of his literary output, but also to ideological considerations that combine to make him the "best" representative of learned "Sinophilia."

KEYWORDS: Victor Segalen, China, reception, Sinophilia, ideology.

$\mathrm{N}$ owadays, the French doctor, archaeologist, novelist, and poet Victor Segalen (1878-1919) is an unavoidable towering figure in modern Sinology and comparative literature studies. ${ }^{(1)} \mathrm{He}$ is considered above all to be the founder of an intercultural poetics between East and West. But despite the number of studies devoted to him in recent years, very few Western researchers have taken any interest in the reception of his work in China. By focusing on the latest research by Chinese specialists on the author of Stèles, this article will be a critical attempt to show that Segalen owes his undeniable success in China not only to the intrinsic worth of his literary output, but also to ideological considerations that combine to make him the "best" representative of learned "Sinophilia." The emergence of Victor Segalen in China as a leading French author has occurred in the context of increasing globalisation, which has seen the proliferation of cultural exchanges between China and the West over the last 20 years. A clear indication of this was the creation in 2007 of a Victor Segalen Foundation, with Valéry Giscard d'Estaing as its honorary chairman and with a goal of developing "a dialogue between Chinese and French cultures." (2) Segalen's official recognition is shared on the Chinese side; not only have the majority of his works been translated into Chinese over the last 25 years, but he appears to be on the way to institutionalisation in China as a figure of Franco-Chinese friendship. To give a more concrete indication, an international conference entitled "Cross-writings France/China: Following in the Footsteps of Victor Segalen" was held at Fudan University in April 2007, sponsored jointly by the French Embassy's Cultural Services and the bank BNP Paribas. ${ }^{(3)}$ More recently there was an exhibition of Stèles at the National Library of China in September 2012, followed by talks and film shows. ${ }^{(4)}$ The breadth of coverage and the intense interest in these events suggest that Segalen is now the beneficiary of official recognition from the French and the Chinese sides alike.

Segalen's reception in China developed in roughly two stages. Contrary to what he has become today, i.e. half author/Sinologist and half theoretician of the "Diverse," Segalen was initially presented to the Chinese public under the name Se Jialan 色迦蘭 as a positivist archaeologist like Paul Peillot. In fact his Chinese translators quickly took an interest in his Premier exposé des résultats archéologiques obtenus dans la Chine occidentale par la Mission Gilbert de Voisins, Jean Lartigue et Victor Segalen (First Report on the Archaeological Findings in Western China by the Gilbert de Voisins, Jean Lartigue and Victor Segalen Expedition). (5) This collection of archaeological reports, intended for specialist readers, was translated by the celebrated historian Feng Chengjun. It was first published in December 1930 by the Shangwu yinshuguan publishing house, that is to say 16 years after the end of the expedition, and it was reissued in 1932, and yet again more recently in 2004 and 2011. This translation appeared under the title of Zhongguo xibu kaoguji (Account of the Archaeological Expedition to Western China), but its distribution in the Republican period seems to have been rather limited on account of the socio-political disturbances in China at the time. These even left their mark on the 1932 edition, where an editorial note appended to the inner cover deplores a Japanese bombardment that damaged its printing works in Shanghai.

1. In this article I have benefitted greatly from the insightful suggestions of Richard Serrano, for which I am very grateful. I would also like to give special thanks to Luc Thominette, Ludivine Colas, and Gilles and Marie-Claire Brunner, who kindly agreed to read it through and make the necessary corrections.

2. "Création de la Fondation Victor Segalen" (Creation of the Victor Segalen Foundation), the Victor Segalen Foundation website, http://segalen.org/fr/la-fondation/la-fonda (accessed on $13 \mathrm{Sep}-$ tember 2015)

3. There is also a report of the proceedings by Sun Min in Zhongguo bijiao wenxue (Comparative Literature in China), Vol. II, 2008, pp. 90-93.

4. Bei-Weikeduo Xiegelan zhanlan zhaodaihui zai guojia tushuguan juxing (The Reception for the "Stèles - Victor Segalen" Exhibition Was Held at the National Library of China), National Library of China website, www.nlc.gov.cn/newgygt/gnwjl/jltx/mllb/jltx041/jldt_041/201210/t2012102 2_67197.htm (accessed on 30 October 2015).

5. Henri Bouillier, Victor Segalen, Fuvres Complètes (Complete Works), Vol. II, Cycle Chinois (Chinese Cycle), Paris, Éditions Robert Laffont, 1995, pp. 909-1065.

6. Zhongguo xibu kaoguji (First Report on the Archaeological Findings in Western China by the Gilbert de Voisins, Jean Lartigue, and Victor Segalen Expedition), translated by Feng Chengjun, Shanghai, Shangwu yinshuguan, 1932 
Victor Segalen, Lenei Laisi (René Leys), Trans. by Mei Bin,

Beijing, Joint Publishing Company, 1991, 260 pp.

\begin{tabular}{|l|l}
\hline & $\begin{array}{l}\text { Victor Segalen, } \\
\text { Bei (Stèles), } \\
\text { Trans. by Che Jinshan and } \\
\text { Qin Haiying, } \\
\text { Beijing, Joint Publishing Company, 1993; } \\
2^{\text {nd }} \text { edition: Shanghai, Shanghai } \\
\text { renmin chubanshe, 2009, 167 pp. }\end{array}$ \\
\hline & $\begin{array}{l}\text { Victor Segalen, } \\
\text { Xie Gelan Zhongguo shujian } \\
\text { (Segalen's Letters from } \\
\text { China), } \\
\text { Trans. by Zou Yan, } \\
\text { Shanghai, Shanghai shudian chubanshe, } \\
\text { 2006, 270 pp. }\end{array}$ \\
\hline
\end{tabular}

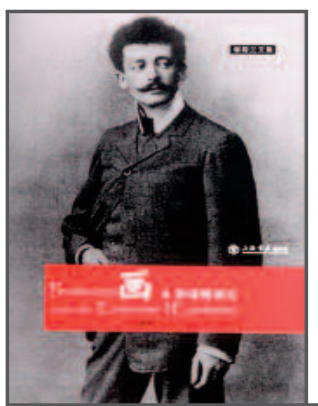

Victor Segalen,

Hua \& yiyu qingdiao lun

(Paintings and Essay on

Exoticism),

Trans. by Huang Bei,

Shanghai, Shanghai shudian chubanshe, 2010, 365 pp.

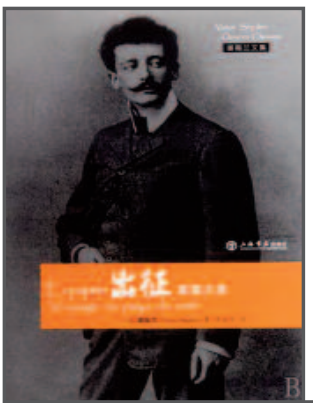

Victor Segalen, Chu zheng: zhenguo zhilü (Venturing Out: Journey to the Land of the Real), Trans. by Li Jinjia, Shanghai, Shanghai shudian chubanshe, 2010, 172 pp.

Victor Segalen,
Shihua suibi (Essays on
Painting and Poetry),
Trans. by Shao Nan
and Sun Min,
Shanghai, Shanghai shudian chubanshe,
2010,203 pp.

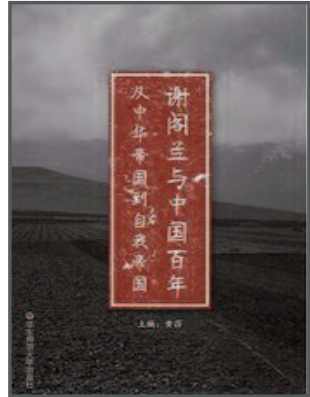

Huang Bei (ed.),

Xie Gelan yu Zhongguo bainian: cong Zhonghua diguo dao ziwo diguo (Segalen and China after 100 Years: From the Empire of China to the Empire of the Self), Shanghai, Huadong shifan daxue chubanshe, 2014, 405 pp.

After a lengthy interval of several decades, Chinese intellectuals seem to have taken a renewed interest in Segalen in the 1990s. This period has seen the appearance of a series of translations and commentaries about him. It must be pointed out that by this time Segalen had acquired a new Chinese patronymic, Xie Gelan 謝閣蘭, which means literally "pavilion and orchids of the Xie family." Compared with Se Jialan 色迦蘭, whose archaic resonance recalls transliterated Sanskrit diction, Xie Gelan conveys a distinctly Chinese tone. This shifting tonality in his name coincides with a shift in interest towards Segalen's non-referential or non-mimetic works. So it is useful to set out, in chronological order, a list of all the recent publications on Segalen in the People's Republic of China:

- Lenei Laisi (René Leys), trans. by Mei Bin, Beijing, Joint Publishing Company, 1991, 260 pp.

- Bei (Stèles), trans. by Che Jinshan and Qin Haiying, Beijing, Joint Publishing Company, 1993; $2^{\text {nd }}$ edition: Shanghai, Shanghai renmin chubanshe, 2009, 167 pp.

- Xie Gelan Zhongguo shujian (Segalen's Letters from China), trans. by Zou Yan, Shanghai, Shanghai shudian chubanshe, 2006, 270 pp.

- Xie Gelan wenji (Collected Writings of Segalen), Shanghai, Shanghai shudian chubanshe, 2010. This collection consists of three books: Hua \& yiyu qingdiao lun (Paintings and Essay on Exoticism), trans. by Huang Bei, 365 pp.; Chu zheng: zhenguo zhilü (Venturing Out: Journey to the Land of the Real), trans. by Li Jinjia, 172 pp., and Shihua suibi (Essays on Painting and Poetry), trans. by Shao Nan and Sun Min, 203 pp.

- Huang Bei (ed.), Xie Gelan yu Zhongguo bainian: cong Zhonghua diguo dao ziwo diguo (Segalen and China after 100 Years: From the Empire of China to the Empire of the Self), Shanghai, Huadong shifan daxue chubanshe, 2014, 405 pp. This volume contains a collection of essays from a dozen or so Segalen specialists, such as Marc Fontana, Philippe Postel, Rémi Mathieu, Marie Dollé, Shao Yiping, Huang Bei, Qin Haiying, and Che jinshan, as well as several poems inspired by Segalen, notably one by François Cheng entitled L'un vers l'autre, en voyage vers Segalen (One Towards Another: Travelling towards Segalen). It is especially significant that this book first appeared at the Paris "Salon du Livre" in March 2014 as part of a series of events focused on Shanghai, the special guest city at the Salon. ${ }^{(7)}$

\section{Chinese perceptions of Segalen's intercultural poetics}

We have to note that for many Chinese translators and commentators, Segalen has acquired a very special status: with the passage of time he has

"Shanghai Will Be the Guest of Honour at the $34^{\text {th }}$ 'Salon du Livre' in Paris from 21 to 24 March 2014," Paris Salon du Livre website: www.salondulivreparis.com/Programme/Actualites/Shanghai-ville-invitee-d-honneur-2014.htm (accessed on 16 September 2015). 
become a somewhat idealised figure embodying the virtue of being the first French writer to know Chinese and to have come to love China's ancient culture. This repeated attribution is also echoed in the views of Édouard Clissant, for whom Segalen is "a revolutionary poet" who "raised the issue of global diversity" and "fought against exoticism as a complacent form of colonisation." (8) This suggests that Chinese academics' rediscovery of Segalen in the 1990s partook of the overall Sinification of Segalen studies that had developed in France since the sixties, and that Chinese critics are largely reliant on the theses advanced by their Western counterparts. This suggestion of a retroactive influence is confirmed by the fact that the new generation of Chinese Segalen specialists were mostly trained in French or comparative literature. Several of them have even presented their doctoral dissertations on Segalen under the supervision of French scholars specialising in that author's work. Such are the cases of Qin Haiying, Huang Bei, Shao Nan, and Sun Min in particular, whose doctoral theses were supervised by Georges Mailhos, ${ }^{(9)}$ Michel Murat, ${ }^{(10)}$ Christian Doumet, ${ }^{(11)}$ and Marie Dollé. (12) So this is bound to raise questions about the originality of this extremely positive image that the Chinese critics bestow on Segalen. Could it perhaps originate in the French hermeneutic tradition that enshrined that writer in the 1960s and which has gained ground in the West ever since? In other words, is Segalen's prominence in China due primarily to his promulgation by his Western partisans and their Chinese followers? To answer these questions it is helpful to refer to an intriguing example showing that Segalen's reputation in China is the outcome of a complex intercultural development that was not instigated by the Chinese critics alone. In one of his conference speeches delivered at Beijing University in 1989, the American Sinologist Jonathan Spence cites Segalen, and especially his novel René Leys, as an outstanding example of the "Western imaginative literature about China" (guanyu Zhongguo de xiangxiang wenxue) that resurfaced during the First World War. ${ }^{(13)}$ Not only did Spence provide his Chinese audience with a summary of the novel, but he also drew attention to the metaphorical reach of the "underground city" (dixia chengshi) that Segalen's René Leys locates under the Forbidden City. Spence points out that at the novel's beginning, René Leys tells Segalen everything about the underground city beneath the Forbidden City; and it is here that for Spence the novel introduces an imaginary scene whose structure reminds him of Calvino and Borges, two authors he proposes to analyse in the final session of his talks. ${ }^{(14)}$

The well-known contemporary Chinese poet Xi Chuan, who is also a native of Beijing, discovered René Leys thanks to Spence, ${ }^{(15)}$ and was astonished by Segalen's "clairvoyance," which seems to have anticipated the ironic fate that befell Beijing in the 1960s:

Segalen's storytelling is not without its faults, but his ebullient imagination inspired Calvino, and he was perhaps also a precursor of Borges, who was well acquainted with labyrinths and nightmares. It is even more astonishing to realise that Segalen's phantasm was transformed into reality by Lin Biao. ${ }^{(16)}$ Before crashing in Öndörkhaan, Lin had sent many people into the underground cellars to prepare for war. At that time I was still a young lad, and every time I heard the alarms sounding, I would immediately rush towards the air-raid shelters filled with unending hatred for the Soviet revisionists and the American imperialists. Down in the shelters I imagined Soviet or American missiles and atomic bombs exploding in my vast socialist motherland. That is how I grew up, plunged into an imaginary ha- tred. As for the underground sites, some of them are being made into commercial centres. When I had got over my puberty tormented by migraine, some of those sites were transformed into secret brothels (...). You need only build fantasies about Beijing, and Beijing will fulfil your fantasies. ${ }^{(17)}$

It is very interesting to note that, thanks to Jonathan Spence and Xi Chuan, Segalen was suddenly promoted to the leading ranks of authors such as Borges and Calvino. Admittedly, these two authors do construct towns or labyrinths with a Chinese flavouring in "The Garden of Forking Paths" and Invisible Cities respectively, but in them China is not restricted to being an exotic background as in René Leys; rather, it is expanded to acquire a universal symbolic range of meaning. Be that as it may, thanks to its introduction via an American Sinologist, René Leys seems to have inspired a poet from Beijing three quarters of a century after its first appearance in France. This trajectory is all the more unexpected in view of the fact that René Leys was initially aimed at an interwar French readership interested in Far Eastern exoticism. It should also be noted that Xi Chuan treats Segalen's "clairvoyance" with a self-mocking lightness of touch and that this "acute" perception is not to be taken seriously. In fact, later in his essay Xi Chuan observes that, just like Marco Polo, Segalen appears to have misunderstood Beijing, but they both "succeeded where they failed, that is to say that they succeeded in making Beijing more mysterious." (18) Xi Chuan takes it as read that Beijing, considered as a metonymy for the whole of China, is by definition impenetrable to the Western mind. Therefore, even if Segalen completely distorted its image, this betrayal is ultimately excusable. We will see how Chinese critics, following Xi Chuan's example, display unstinting tolerance towards the lapses in Segalen's China-inspired tales, and that Segalen

8. Édouard Glissant, Introduction à une poétique du Divers (Introduction to a Poetics of the Diverse), Paris, Gallimard 1996, pp. 76-77.

9. Qin Haiying, "Empire de Chine, empire de signes. L'œuvre poétique de Victor Segalen" (Empire of China, Empire of Signs: Poetic Works of Victor Segalen), doctoral thesis directed by Georges Mailhos, University of Toulouse 2, 1987, www.theses.fr/1987TOU20002 (accessed on 13 September 2015).

10. Huang Bei," Peintures de Segalen et Cent Phrases pour éventails de Claudel : un dialogue au travers de la peinture extrême-orientale" (Paintings by Segalen and Hundred Movements for a Fan by Claudel: A Dialog through Far Eastern Painting), doctoral thesis under the direction of Michel Murat, University of Paris IV, 2005, www.theses.fr/2005PAO40083 (accessed on 13 September 2015).

11. Shao Nan, "Dialogues entre Segalen et la culture chinoise : le cas de la conception segalenienne de la vie et de la mort" (Dialogs between Segalen and the Chinese Culture:The Case of the Segalenian Conception of Life and Death), doctoral thesis under the direction of Christian Doumet to be defended, University of Paris 8, www.theses.fr/s 1143159 (accessed on 13 September 2015).

12. Sun Min "Le regard français sur la peinture chinoise au tournant des XIXe et XXe siècles" (The French Viewpoint on Chinese Painting in the Late Nineteenth and Early Twentieth Centuries), doctoral thesis supervised jointly by Marie Dollé and Fudan University, Shanghai, and defended on 16 December 2009. Cf. Website of the Centre for the Studies of Linguistic and Literary Relations and Contacts, Jules-Verne University of Picardy, Marie Dollé page, www.romanesques.fr/listeauteurs/ marie-dolle (accessed on 13 September 2015).

13. Jonathan Spence, Wenhua leitong yu wenhua liyong: Shi Jingqian Beida yanjianglu (Culture Equivalence and Culture Use: Speeches Delivered by Jonathan Spence at Peking University), translated from English by Liao Shiqi and Peng Xiaoqiao, Beijing, Beijing daxue chubanshe, 1989, p. 79.

14. Ibid., p. 83

15. Xi Chuan, Shenqian - Xi Chuan shiwenji (Collected Essays and Poems by Xi Chuan), Beijing, Zhongguo heping chubanshe, 2006, p. 195

16. Lin Biao (1907-1971) was a Chinese general and politician who played a major role in the Cultural Revolution. According to the Chinese government, Lin plotted against Mao and, being denounced, fled toward the USSR in an aircraft that ran out of fuel and crashed in Öndörkhaan, Mongolia, on 13 September 1971 (author's note)

17. Xi Chuan, Shenqian - Xi Chuan shiwenji (Collected Essays and Poems by Xi Chuan), op. cit., pp. 195-196.

18. Ibid., p. 198 
even seems to acquire a certain recognition for the poetic force through which he profoundly distorts Eastern realities.

The influence of Jonathan Spence on Xi Chuan certainly exemplifies a broader trend. This circulation of references to Segalen's works can be seen in operation between other French and Chinese critics. An example of this direct influence is Henry Bouillier, who is a primary reference source for most of the Segalen specialists in China. This professor of French literature at the Sorbonne was the first French academic to take an interest in Segalen. According to one of his contemporaries, Jean-Maurice Gautier, it was "through Bouillier's efforts that Segalen was admitted to the literary Pantheon." (19) In his doctoral thesis of 1961, Bouillier put forward a series of interpretations of Segalen's poetry that have been reiterated constantly by critics after him. Clearly, the exegetical model established by Bouillier has left its mark on his Chinese successors. The latter often begin their interpretations by borrowing some opening hypotheses from Bouillier before proceeding to their own readings, which sometimes correct certain failures of precision that a French eye can hardly detect. An example of this is $\mathrm{Li}$ Jinjia, the translator of Équipée, who goes so far as to warn Chinese readers against Henry Bouillier's limitless admiration for Segalen:

With regard to the quality of the language, Équipée is not perfect. This is not only due to the patent breaks and omissions in chapters 11 and 19, which obscure the meaning, but also to redundancies in the syntax and lexical choices (...). When the critics comment on Équipée, they often quote Henry Bouillier's opinion that it is a "luminous work" constructed in "firm and muscular prose," which is in fact grounded in excessive eulogy (...). Segalen was a writer still working on his style. If he had not died so young, he would certainly have polished Équipée to make it a major work. ${ }^{(20)}$

\section{Infidelity to Chinese texts as creative "enrichment"}

It is interesting to note that, however much they may disagree with Bouillier's exegesis, Chinese critics refuse to question Segalen's genius and the literary value of his works, doubtless fearing to call into question the bases of the "Sinophilia" that Segalen is believed to embody. In the preface to her Chinese translation of Stèles, Qin Haiying evokes Segalen's well-known metaphor in his letter to Henry Manceron, referring to his constant "transfer of the Empire of China to the empire of the self." Clearly Qin is borrowing from Bouillier one of his leading ideas about Stèles. Just like Bouillier, Qin hotly defends the idea of the intentional infidelity in Segalen's representation of the Chinese Empire. The only difference between her and Bouillier is that Bouillier seems to place Segalen's personal mythology above the Chinese sources, whereas Qin refuses to entertain such thoughts. Let us first consider what Bouillier writes in his preface to Stèles:

Both spectacle and text simply act as a catalyst or a trampoline for approaching the poem. (...) He was inspired by the texts while endlessly betraying them, by lending them a richness of his own, unsuspected by everyone else. For him they were merely the poem's negatives, literally the clichés without an image until they were developed in a flash by poetic grace. (...) therefore he bestowed upon the often poor and dry Chinese texts an infinite reach (...) [but] achieving a truly original work on the basis of Chinese material. If he chose to assume the mask of another culture, it was because that gave him the best way to multiply the allusions, suggestions, and symbols necessary for his allegorical conception of poetry. ${ }^{(21)}$

Obviously Bouillier does not hide his disdain for the Chinese sources, which are often "poor and dry." For him, the transfer of the Empire of China to Segalen's self has its corollary in the enrichment of the Chinese text, and this is effected through the multiplication of poetic allusions and the development of the imageless negative plates (clichés). This presupposition of Segalen's superiority is not untainted by Henry Bouillier's French form of eurocentrism, compounded by the fact that he does not even have any knowledge of Chinese. For her part, Qin Haiying turns out to be more nuanced:

Of course, this type of transfer is present in various aspects of Stèles, such as its structure, form, and content, especially in the role played by the Chinese epigraphs and the use of Chinese anecdotes. (22) (...) The French specialist in Segalen studies, Henry Bouillier, believes that for Segalen China is a vast "metaphor" (yinyu) (...). This suggestion is very pertinent, for it acknowledges the poet's originality while giving substance to his relationship with China. The "metaphor" is based on analogy and the comparison between the term being compared and the comparing term. This is basically a transfer of meaning that, in Segalen's case, refers us to the transfer of "the Empire of China" to "the empire of the self." In our view, such a transfer, whose precondition is a deep knowledge of Chinese culture, will perhaps be better able to make us reflect than any direct and objective description, and to reveal to us the essential questions in the comparative studies of Chinese and Western aesthetics, poetics, and philosophy. (23)

Qin Haiying is a professor of French at the prestigious Peking University, and through her first translation of Stèles in 1993, her articles, and her frequent papers at university conferences, she was more or less the initiator of the rebirth of interest in Segalen in China. Significantly, she broadly accepts Bouillier's thesis, that Segalen's poetic elaboration of his Chinese sources is related to a symbolic transfer of the Empire of China to the empire of the self. But her originality, in comparison with Bouillier, is that she considers the very uneven dose of interculturalism and bilingualism in Segalen's poetics to be a privileged and illuminating form for Sino-French comparative studies. This redefinition of the classic orientalist's "betrayal," of which Segalen was an inveterate instigator, grants him a quite special form of recognition, but without downgrading his Chinese sources. Nonetheless, Qin Haiying does not fail to remark that, even though Segalen may borrow certain stylistic and syntactic traits from classical Chinese, Stèles itself "is quite lacking in any of the savour of Chinese poetry" (bing meiyou Zhongguo shiwei'er). She adds that Segalen's work "rests on a Western metaphysical model of creativity, and in reality it is a continuation of

19. Jean-Maurice Gautier, "Bouillier, Henry. Victor Segalen," Journal de la Société des océanistes (Journal of Oceania Society), Vol. 17, 1961, pp. 86-87.

20. Chu zheng: zhenguo zhilü (Venturing out: Journey to the Land of the Real), translated by Li Jinjia, Shanghai, Shanghai shudian chubanshe, 2010, pp. 15-16.

21. Henry Bouillier, Victor Segalen. Fuvres Complètes (Complete Works), Vol. II, op. cit., p. 29.

22. Bei (Stèles), translated and annotated by Che Jinshan and Qin Haiying, Shanghai, Shanghai renmin chubanshe, 2009, p. 6.

23. Ibid., p. 12 
the Symbolist tradition." Therefore, she concludes, "China is definitely not his final destination" (Zhongguo ziran bushi ta zuihou de guisu). (24) In fact, Qin is far from being the only one to question the Chinese guise with which Segalen adorns himself in Stèles, nor is she alone in mounting an apology at the same time for his rewriting of the original sources in the name of a new poetics. This tendency is shared by Qian Linsen and Liu Xiaorong, who do not hesitate to point out the barbarism of the Chinese epigraph sichou daoxue 撕綢倒血, coined by Segalen and incorporated into one of his "stele" poems, Pour lui complaire. In their view, here Segalen invents an incomprehensible neologism in his expression, sichou 撕綢 or "tearing the silk," modelled on another word liebo 裂帛, which does literally mean "tearing the silk" but always refers figuratively to the "ancient books." (25) Despite this grotesque misunderstanding, Qian and Liu seem highly appreciative of "a certain sadomasochistic dimension" (yizhong nüe yu beinüe de chengfen) in Segalen's work, when the narrator announces that "to please her I will hold out my worn soul, torn apart" and "I will pour out my blood like a drink." (26) For the two Chinese critics, this creation by Segalen out of a fantastically distorted Chinese expression is a virtuoso depiction of "a very strange occurrence in love relationships" (zhe zhenshi qinghai qiguan), which shows how "a marvellous poem is born out of a shallow knowledge of Sinology." (27) Although they cannot dispense with a hint of sarcasm, Segalen's random misinterpretation of his Chinese sources becomes for these Chinese critics a kind of positive merit, which even risks leaving the fully aware reader rather perplexed.

\section{A reconstructed "Sinophilia"}

This contradictory albeit subtle vision of the Chinese Segalen specialists seems to show that for them, Segalen's literary worth consists more in their perception of his "Sinophilia" than in his actual knowledge of Chinese language and culture. Of course, Segalen is indeed in love with China, but with a metaphorical bookish one of his own that has no room for concrete realities. This sublimated "Sinophilia," which crystallised posthumously in the minds of the admirers of Stèles, was doubtless rare among the French Orientalists of the early twentieth century. It goes without saying that the ideological appeal offered by Segalen has not been unnoticed by contemporary Chinese critics, who are collectively thrilled by a Western voice that seems willing to give a certain credit to their ancient culture. Here is an example from Qian Linsen and Liu Xiaorong's review essay, dealing with the "love" felt by Segalen for China:

However little reference we make to his activities in China, we will still understand that Segalen chose China out of love and sincere feelings. (28)

It hardly needs to be said that Segalen's "Sinophilia" is very politically correct in the post-colonial context. Focused completely on his own version of a bygone aestheticised China, Segalen seems to maintain a distance between himself and the colonialist outlook of his time. And some Chinese critics do not fail to emphasise his theory of the "Diverse" based on his egalitarian vision of the other. Thus Shao Yiping, who is a professor of Chinese at Fudan University, observes that Segalen is in the opposite camp from Pierre Loti. He demonstrates this difference by quoting some passages taken from the Essay on Exoticism, where Segalen "accuses" Loti of being a colonialist "exoticist." From this Shao draws the following conclusion: "Nowa- days, even though Pierre Loti still remains better known by the general public, Segalen is way ahead of him in his status in literary history." (29) The same applies to Huang Bei, the professor of French at Fudan University, who also points to the influence of Segalen on Édouard Glissant insofar as the latter has perfected Segalen's conception of the "Diverse." Or more precisely, in Huang's words, "Instead of drawing a line between the you and the I" (buzaishi xieshide niwo fenming), Glissant "puts greater emphasis on the interchanges and the hybridity in his 'Diverse' (qiangdiao duoyuan zhongde jiaoliu yu hunxue)," which is evidence of an even more progressive vision." (30)

In conclusion, Chinese critics seem to give great importance to the Chinese elements incorporated by Segalen into his work. Accordingly, they do not hesitate to launch into philological investigations that sometimes display, with an ironic lightness of touch, Segalen's linguistic inadequacy. Nonetheless, they react more or less approvingly to the distortions in Segalen's representations of the Chinese Empire while admitting that in Segalen's case, Sinological perspicacity is not necessarily to be encountered. Clearly, this tolerance helps to make Segalen a leading figure of the learned "Sinophilia" that has gradually become an institutionalised norm, thanks to the cultural events, conferences, and translations where France and China currently appear to find an especially fertile ground for mutual understanding. Moreover, the official, and rather officious, consecration of Segalen in China finds an echo in the status that Segalen is being given by the theoreticians of postcolonialism, owing in particular to his theory of the "Diverse." Accordingly, it is not surprising to see Chinese critics setting up Segalen in opposition to Pierre Loti, the novelist of the colonial imaginary who provides a convenient contrasting figure, and allying him with Édouard Glissant, whose "poetics of the Diverse" can be seen as a direct descendant of the Essay on Exoticism.

\section{Translated by Jonathan Hall.}

I Bai Yunfei is currently a doctoral student at Rutgers University in the United States. His main field of research is French Orientalism. 131 George Street, Ruth Adams Building, Room 103, New Brunswick, NJ 08901, USA (yunfei.bai@rutgers.edu).

24. Ibid., pp. 11-12

25. Qian Linsen and Liu Xiaorong, "Xie Gelan yu Zhongguo wenhua" (Segalen and Chinese Culture), Zhongguo bijiao wenxue (Comparative Literature in China), Vol. 4, 1996, pp. 52-63.

26. Henry Bouillier, Victor Segalen. Fuvres Complètes (Complete Works), Vol. II, op. cit., p. 74.

27. Qian Linsen and Liu Xiaorong, "Xie Gelan yu Zhongguo wenhua" (Segalen and Chinese Culture), art. cit., p. 55.

28. Ibid., p. 55.

29. Shao Yiping, "Xie Gelan de Zhongguode huanxiang de Zhongguoshi jiedu" (A Chinese Interpretation of Segalen's "Chinese Vision") in Huang Bei (ed.), Xie Gelan yu Zhongguo bainian: cong Zhonghua diguo dao ziwo diguo (Segalen and China a Hundred Years Later: From the Empire of China to the Empire of the Self), Shanghai, Huadong shifan daxue chubanshe, 2014, pp. 162-163.

30. Huang Bei, "Xie Gelan: yongyuan de yixiangren" (Segalen: The Perpetual Outsider), in Huang Bei (ed.), Xie Gelan yu Zhongguo bainian: cong Zhonghua diguo dao ziwo diguo (Segalen and China after 100 Years: From the Empire of China to the Empire of the Self), op. cit., pp. 54-55. 